\title{
Democracia ou oligarquia? \\ o controle invisível da política
}

Roberto Bueno

Democracia: crise e controle oligárquico

A democracia é um valor de trânsito corrente e de fácil receptividade nas sociedades ocidentais contemporâneas, uma aspiração que, ao menos retoricamente, é compartilhada por amplos espectros da humanidade, malgrado existam variações em sua compreensão de fundo e não menos em suas orientações e projeções normativas. Essas variações deram origem a diferentes formatações históricas e inserções geográfico-espaciais, bem como a intensas disputas sobre o seu real significado, apontando para a sua natureza e realidade, a saber, a conflitividade, mas também temperada pelos esforços de equilíbrio, conformando assim o que denominaríamos de equilíbrio instável. Destituída de qualquer possibilidade de essencial pacificação, e com uma dimensão política de tão intensos (e inconclusos) debates, Nancy conclui que, no caso da democracia, do que se está mesmo a tratar é da ausência de significado (Nancy, 2010, p. 79), ao menos de um significado preciso e indebatível, algo fortalecido pela argumentação de Zagrebelsky ao mostrar que a democracia está marcada por uma grande elasticidade, "capaz de dilatar-se quase ao seu bel-prazer" (2011, p. 21). Não obstante, acaso alguma aproximação mais precisa seja possível, sugerimos que ela reside em que, à partida, é assumida a imperfeição como a sua matéria-prima e condição invencível, o que se reflete na atividade política, descolada dos objetivos messiânicos redentores, ou, como diria Todorov a respeito da democracia, "La construction du paradis sur terre ne fait pas partie de leur programme [...]" (2012, 
p. 17). Se é mesmo este o pano de fundo em que uma democracia opera, então, o horizonte das liberdades encontra-se em uma proposta de desequilíbrio estável ou de equilíbrio instável, vetor ao qual apontamos a partir do reconhecimento da sociedade (e de suas instituições) ao compartilhar a ideia de Zagrebelsky de que elas estão marcadas não só pela insegurança, mas também por uma pauta filosófica mais ou menos consciente perpassada por um claro viés cético (2011, p. 9).

A democracia foi consagrada na gramática política como um adjetivo, e de tal modo enraizou-se na cultura política que seus inimigos não ousam atacá-la frontal e abertamente, senão que adotam estratégias paralelas e subterrâneas. Os detratores da democracia guardam a vergonha de cerrar fileiras ao lado dos patrocinadores do nem sempre sub-reptício ataque ao humano, da realização da morte como via para a realização da política, em suma, da organização da barbárie. O coletivo de envergonhados (até agora) em proceder ao ataque direto à democracia retomam o vocábulo e, paralelamente a elogiá-la, abordam-no a partir de um esforço hermenêutico de reordenação profundo. A sua opção semântico-ideológica é simpática a tipologias de regimes muito diversos da democracia, com a qual guardam relação de antagonismo. Não raro descortinam e apontam para horizontes que realizam regimes ditatoriais, que se comprazem com a maquiagem libertária que o conceito lhes confere, visto que reveste o conceito de ditadura desta gramática democrática. A despeito da teoria antitética que ambos representam, a democracia continua a desfrutar de uma aparência altamente palatável e até sedutora, reforçando a ideia de Zagrebelsky de que ela realmente penetra em nossos dias como um verdadeiro ideal de nosso tempo (2011, p. 8). Neste sentido, Gauchet dá um passo adiante ao sugerir que a democracia já não tem inimigos internos declarados (2012, p. 19), posição aceitável tão somente quando entendemos que ela possui uma compreensão unívoca, algo que, de longe, não é o caso.

A multiplicidade de sentidos atribuídos à democracia desenha um cenário de genuína confusão semântica e de orientação para os atores sociais, no qual apenas há convergência quanto ao adjetivo acrescido por todos ao significado da democracia, mas não há convergência sobre o mais relevante, a saber, sobre o seu conteúdo. Mais grave, não apenas inexiste essa convergência, como está instalada a mais radical discrepância sobre o significado e o alcance da democracia, sendo compatibilizada por alguns com a própria ditadura. Essa realidade constitui uma porta aberta para a divergência no plano interno, inversamente ao que indica Gauchet. Nesse âmbito há, isto sim, inimigos, mas eles não se expõem como antanho, através da proposição de regimes alternativos à democracia, senão que, utilizando o vocábulo, propõe-se de dentro a sua ressignificação, orientando sua ação por uma silenciosa colonização semântica. A resposta autoritária das oligarquias à divergência é dura, característica 
de um mundo novo que em seu momento Jaspers descreveu como marcado pelo empenho na destruição de tudo quanto não cabe dentro dele (1933, p. 76).

Os inimigos da democracia podem agir intramuros de forma extremamente eficiente, não mais sendo necessário apontar para cenários radicalmente diversos daqueles que retoricamente dizem defender. Os inimigos da democracia, contrariamente ao que diz Gauchet, existem, mas não de forma explícita, declarados em seu sentido gramatical-ideológico, e assim podem continuar operando tranquilamente no plano interno sem riscos consideráveis, porque "A democracia é um sistema de governo muito complacente. Pode acomodar muita coisa sem abandonar o seu nome" (Zagrebelsky, 2011, p. 9). Antes de assumir publicamente o autoritarismo como via política, convém utilizar de forma eficiente o discurso solapador da democracia sob a proteção de suas instituições. Sem embargo, esse posicionamento não as retira do mundo nem minimiza seu impacto na política interna de cada Estado. O fato é que sua ação se dá de forma sorrateira, voltada à ressignificação semântica de um vocábulo de apelo popular, visando à reforma das instituições, mas desatendendo à sua constituição formal, mesmo pela via material ou de sua prática ou. Em essência, isso equivale a uma dura e radical viragem política, cuja profundidade e relevância não são percebidas pela esfera pública, dado que os oligarcas não tornam públicas nem explicitam as divergências e fogem aos embates teóricos, permanecendo atentos ao necessário triunfo no campo semântico. Uma das consequências desta estratégia de alterar o fundo da democracia, mas não a sua superfície visível, é causar uma progressiva desconfiança e distanciamento popular, o que Rosanvallon descreve como paulatina percepção de que a política merece ser "violentamente rejeitado, em comparação com o que é a estrutura da vida das pessoas" (2014, p. 28).

Essa é uma atividade oculta intestina, desenhando um cenário em que a democracia é finalmente transformada apenas na esfera discursiva pública, enquanto é corroída, desde dentro, em adjetivo publicamente compartilhado. Isso se deve essencialmente à disseminação horizontal da ideia do valor da democracia, da propaganda e da forte publicidade em torno do conceito, ainda que sua vivência não seja compatível com os princípios divulgados e que supostamente comporiam a prática das instituições. A progressiva maleabilidade de que foi revestido o conceito tornou-o aproveitável por diversas possibilidades de organização social, embora todas elas mantenham em comum o discurso pró-libertário e a participação popular, mesmo quando nada disso tenha espaço no mundo dos fatos. Malgrado as estratégias de controle e as manipulações sofridas pela cena pública, em que os discursos político-democráticos são descalibrados pelas práticas oligárquicas, a democracia vem servindo continuadamente como fonte de inspiração coletiva. Ainda estritamente do ponto de vista conceitual, ela não é compartilhada em sua inteireza por todos os setores, mas tem 
servido como ponto de atracação para uma espécie de discurso plural e tolerante capaz de ancorar esperanças e conceder mediana estabilidade ao sistema controlado de forma hábil pelas oligarquias no poder.

A crise da democracia contemporânea é alimentada por constantes recriações e redimensionamentos políticos sob o manto da ordinária ocorrência da vida nas sociedades democráticas, algo descrito por Rancière (2012, p. 18) como derivação da intensidade da vida democrática. As democracias em operação nos Estados ocidentais descuidam de conhecer as excepcionalidades e as estratégias desenvolvidas por grupos constituídos à margem do Estado de Direito e de sua constitucionalidade, no sentido de solapar suas bases e passar a aceitá-los como a sua própria essência. Desse modo, desconsideram a descrição de Enzo Mauro (2011, p. 12) de que a democracia liberal está instaurada precisamente para tutelar o cidadão contra o abuso de poder e, assim, o Estado de Direito consistiria em uma espécie de defesa institucional em favor dos indivíduos em seu confronto com o poder.

Os grupos apropriadores do poder o operam em espaços discretamente comunicados com câmaras ocultas, ambos de nula visibilidade na esfera externa, onde reside a soberania política democrática, atuando como se de uma estrutura de poder legítima se tratasse, como se um órgão ou agência legalmente instalada no organograma do Estado fossem. Entretanto, rigorosamente, operam às escuras e, paradoxalmente, à margem e dentro do Estado, deslocando seus órgãos da execução de sua função precípua, virtualmente apropriando-se deles (Mészáros, 2015, p. 94). Manipulando-os, os grupos do poder impedem os titulares da democracia de assumir qualquer posição de responsabilidade, pública ou privada, em face das decisões das oligarquias. Rigorosa e integralmente, eles fogem a uma concepção estabelecida e compartilhada do alto valor de que todos os cidadãos respondam de forma igualitária perante a sociedade pelo conjunto de suas ações. Sem embargo, outra é a percepção das oligarquias isoladas em salas contíguas às do poder, cujo sentido último e exclusivo de atuação é o de desconstituir o mundo dos direitos, sociais e individuais, sempre sob a retórica da manutenção das supostas condições de governabilidade, quando mais não passam da manutenção do status quo durante e após a crise.

A retórica da necessidade de alçar a economia ao controle da política pretende apresentar as condições de manutenção do sistema sobre a vida do homem ordinário e suas próprias condições de existência e, se necessário, desenhando um horizonte impensável de falir a massa em prol do asseguramento das regras sistêmicas. As consequências de tais intervenções políticas e econômicas restam sempre à distância segura da vinculação com os seus beneficiários, cujas imagens ficam preservadas do escrutínio dos olhos públicos, sendo atribuído à sociedade o dever de arcar com os custos quando prejuízos derivem dessas decisões macro sobre os rumos do 
Estado. Mas, é certo, em nenhum caso serão os cidadãos os titulares coletivos dos benefícios que eventualmente redundem dessas decisões, imediatamente alocadas para os oligarcas.

Esse ataque constante aos direitos individuais e coletivos que apenas puderam ser tecidos a longo prazo e em circunstâncias penosas perante as estruturas medievais de poder ocorre sob a maximização do discurso do impacto das crises econômicas geradas pelos próprios oligarcas no poder, criando o domínio do fascismo da insegurança, cujo terror visa a aplainar o terreno para a resignação em relação aos recortes de direitos, individuais e sociais, de liberdades, tanto quanto de prestações sociais por parte do Estado. A realização desse movimento é de superlativa densidade destrutiva dos fundamentos da democracia, que, por definição, supõe o compartilhamento de mínimas visões acerca da distribuição dos benefícios sociais e das garantias outorgadas aos grupos e aos indivíduos que os compõem. É da agudização desse conjunto de percepções acerca do enlace protetivo da legislação em vigor que se constitui um forte laço em prol das instituições democráticas, ou, observado o seu progressivo esgarçamento, paralelamente, cumpre resistir à desconstituição e ao esvaimento das instituições democráticas.

A estratégia de desconstrução do mundo dos direitos apenas disfarça o interesse em manter as condições e as taxas de remuneração do capital em suas mais diversas formas de relações econômicas no mundo. É assim que, por exemplo, o direito à propriedade e aos frutos do trabalho da oligarquia permanece sempre intocável e imune às crises, e, portanto, a propriedade já não está constituída em sua intangibilidade, senão para alguns grupos oligárquicos. Por seu turno, o conjunto da população é quem suportará os custos dos prejuízos que o sistema venha a sofrer por meio do recolhimento de tributos que não alcançam materialmente os organizadores ocultos do sistema e, quando muito, alcançam apenas formalmente, plano do qual logram desviar-se com tranquilidade mediante seu perfeito domínio das vias jurídicas; e nisto, certamente, sequer restam vestígios do contrato social liberal que, ademais, se esfuma teoricamente ao deslocar uma das partes dos benefícios e sobrecarregá-la com ônus, pois isto é realizar o império da força típico do estado de natureza sob o manto formal protetor da retórica liberal do mundo dos direitos. Nesses termos, portanto, o contrato social como princípio regulador da democracia, sobre a qual deveria atuar como estabilizador de crenças e expectativas, migra para outra esfera, francamente desestabilizadora dos fundamentos da democracia à qual deveria servir.

Nesse cenário, portanto, há um conjunto de titulares meramente formais de direitos, que sobre eles não deliberam nos momentos de crise, mas que têm seus direitos considerados como objeto de deliberação pelos grupos executivos da oligarquia inseridos tanto na esfera legislativa quanto na administração pública. Esse 
movimento de desconstituição dos direitos é uma das vias expressas para a desarticulação da democracia e que a coloca em crise na contemporaneidade, mesmo quando sob o artificioso rótulo de que tais ações são tomadas com vistas à proteção da democracia; afinal, é certo, meios antidemocráticos nunca visam à proteção ou à reinstauração da democracia, senão à radicalização das tradições que lhe reservam desprezo e esforços corrosivos.

Este esforço desconstitutivo continuado da corrosão da democracia denota uma luta sempre renovada que corrobora a atualidade do embate sisífico entre o mundo do capital e do trabalho, cujo discurso foi sendo alterado com o correr dos tempos, mas de forma alguma conheceu modificações sem vaporizar a essencialidade do sangue vertido, pois o destino reservado entre a fria espada e a dureza da cruz nunca conheceu mais destinatários do que os de sempre. $\mathrm{O}$ estado do poder econômico desliza sua habilidade comunicativa a fim de seduzir mentes para seu campo de ação: entre as talentosas, apelando para as debilidades da alma humana; entre o conjunto da massa, pela não menos hábil campanha que já não mais promete as virtudes do além pela via teológica, senão que lhe promete as benesses materiais nesta vida. Que os homens procedam à reabsorção do econômico pela esfera do político e que desloquem o domínio exercido pela retórica e pela prática econômica não é uma tarefa menor dos dias que correm.

No balanço das décadas, o discurso dos direitos precisa ser matizado pelas oligarquias, que hão de conter o embalo das massas em suas demandas por direitos e avanços sociais, pois não se trata, como nunca se tratou, de um jogo de soma zero. A oligarquia no poder não hesita em sofisticar o discurso, e a cada uma das crises que se sucedem é necessário apontar para um cenário ainda mais radicalmente desesperançador, a fim de que seja possível dar alguns passos para trás com a aquiescência coletiva. Esses passos acordados com os trabalhadores permitirão que durante alguns anos todas as lutas sejam desenvolvidas no sentido de recuperar o território dos direitos perdidos, até que, uma vez mais, outra crise sobrevenha e o discurso apocalíptico, ainda mais sofisticado, ganhe as ruas pelo impacto causado pelas mídias e, uma vez mais, os direitos serão afetados.

É realizado um contínuo, mas cessante, intercalamento entre avanços e retrocessos dos direitos dos trabalhadores, construindo um cenário aparentemente vivo e talhado para que os indivíduos mantenham a esperança, em seu mais alto nível, de que os direitos estão a avançar. Tal deslocamento do direito é costurado por oligarcas que solapam os melhores resultados das atuações das forças históricas. São agentes que desempenham às escondidas nas antessalas do poder e nos recônditos dos lugares públicos, os quais, precipuamente, deveriam estar ocupados em articular esforços para projetar um futuro radiante. Nesse sentido, portanto, a oligarquia estaria atuando 
de forma distanciada da afirmação do mundo dos direitos, procurando desarmá-lo desde dentro, esvaziá-lo de seu melhor conteúdo histórico, mantendo-o tão somente como pura retórica disponível e apropriável a todo momento para que o status quo conserve suas expectativas de estabilidade e equilíbrio e, assim, mantenha tutelados os seus interesses oligárquicos, mesmo a custo de concessões pontuais necessárias para garantir a despressurização do sistema sociopolítico ocultado sob o discurso de avanços sociais.

Seguindo essa linha, Gauchet (2012, p. 57) sustenta que a atual crise da democracia remete a uma crise de seus fundamentos que, segundo sua hipótese, seria um movimento causado pela própria dinâmica interna da democracia antes que por inimigos externos. Sugerimos que essa crise apresenta uma dupla face que precisa ser destacada. De um lado, a crise é posta em marcha através de práticas distanciadas de seu titular, o povo; de outro, a intervenção de forças econômicas antidemocráticas que operam em seu núcleo corroem as formas teóricas da democracia. Essa dupla ação desarticula empiricamente a formatação prática da democracia, e sobretudeo as oligarquias atuam no sentido de ressignificar o conceito, embora não sejam autorizada para isso. Agem alterando importantes referenciais teóricos pela via da introdução sub-reptícia de conceitos econômicos transladados ao político com efeito de perfeita colonização, a ponto de serem apresentados em seu conjunto como se uma única forma estrutural estivesse disponível para a organização social. Essa é uma força que se apresenta não raramente como apolítica, técnica, voltada para a instrumentalização dos recursos para otimizar a produção e, desse modo, interpretar a política como mero instrumento colonizável para a conquista de fins econômicos. Finalmente, esse seu movimento tem amplo comprometimento político, mesmo porque, com efeito, suas ações destituem desta posição o seu real titular.

O aprofundamento desse duplo processo de ressignificação desautorizada pelo povo e a intervenção de forças econômicas de forma subterrânea marcam indelevelmente o caminho para um progressivo distanciamento da prática da democracia daquela que é, em sua essência, a sua melhor formulação teórica. Inexoravelmente, as percepções populares sobre os efeitos visíveis desse duplo movimento geram descrédito e desconfiança pública nas instituições democráticas. Trata-se de um movimento gerador de clara deslegitimação da democracia, levado a termo dentro de sua estrutura de funcionamento (ver Rancière, 2010), apontando para o esgotamento do conteúdo da titularidade do poder, isto é, dissolvendo o povo na mais pura e bem-acabada impotência política sob perfeito travestimento formal de suas formas e instituições, devidamente esvaziadas de potência para interagir e reagir contra os detratores do sistema. Esse sentimento de impotência é alimentado pelas oligarquias, que não mantêm relação íntima de distanciamento com a cultura autoritária e nem 
um pouco constrangidas ficariam de ter de conduzir um regime político dessa ordem caso dispusessem de capital político e apoio para tanto.

Conforme apontamos, a hipótese com que trabalhamos aqui é de que a democracia está em crise devido à intervenção dessas forças não explícitas que operam corrosivamente em seu seio contra a comunicação e a decisão coletiva de matérias políticas de vital interesse público. Essa ação desarticula a projeção empírica do conceito central da democracia, vale dizer, da participação. Nas esferas de sua admissão formal os atores políticos são mantidos à distância das matérias de fundo, dos temas que realmente tocam o coração do sistema de funcionamento do mercado e da economia em geral, cujas categorias e conceitos são naturalizados, dogmas mantidos pelas célebres figuras do Olimpo da economia com sua linguagem específica a manter ainda mais alheios os indivíduos não iniciados no rito do domínio pela via da técnica. Esses atores são considerados agitadores, provocadores de instabilidades, ameaças radicais à paz social e, no limite, os detentores do poder os proscrevem, pois a sua visão de futuro enfrenta o conservadorismo daqueles que dissimuladamente pretendem cristalizar o passado sob o discurso da aplicação da técnica ao campo do político e da economia. Atribuir a tais atores a responsabilidade pelas instabilidades é mero pretexto para o enfrentamento, pois, como bem reconhece Jaspers, a situação de estabilidade é impossível, inserta em uma existência sempre imperfeita e insuportável (1933, p. 66). Desconhecer essa inexorável dimensão do real é uma via para a desconstrução explícita do modelo mínimo de democracia avançada, pois esta requer um futuro aberto e descolado de predeterminaçóes, disponível para a contestação e a reconstrução por parte de seus cidadãos, enquanto o processo inverso é o sugerido pelas oligarquias.

Nesse sentido é que indicamos preliminarmente que a democracia tem sido alvo de uma estratégia de ressignificação desautorizada, menos de sua teoria, que precisa continuar sendo publicizada nos mesmos patamares, senão em sua prática, mantendo os vocábulos que historicamente compõem a gramática da democracia, mas transformando seu sentido tanto quanto necessário para que as oligarquias possam avançar em sua sanha de domínio econômico. A colonização dos mundos da cultura e da política não passa de meros instrumentos úteis em detrimento da pura força, reservada para momentos de stress institucional, dado o seu mais baixo nível de eficiência no controle das massas a médio e longo prazo.

\section{Crise moderna: mercado e poderes ocultos}

A intensa crise política que envolve diversos Estados ocidentais é, em verdade, uma crise da democracia contemporânea e, nesse sentido, com ramificações na própria 
cultura de época (ver Galli, 2013; Mcafee, 2008). Além disso, diríamos que não pode ser desconsiderada a sua vinculação com o recrudescimento da cultura individualista, radicalmente atomizante, narcísica e sistemicamente voltada para o aculturamento ao consumo, ainda que inexistam necessidades específicas a serem cobertas por tal comportamento econômico. Este agir cego alimenta um sistema produtivo cuja roda passa a girar praticamente de modo automático, destituindo o ser da centralidade da organização da sociedade humana em prol de uma nova sacralidade, a saber, um produto ou objeto cuja capacidade fugaz de promover satisfação não é casual, pois essa contínua demanda é a mola propulsora do sistema, instância da qual virtualmente o sistema se alimenta de modo voraz ao absorver e consumir a consciência reflexiva de todos no momento presente e, assim, hipotecar o futuro coletivo.

Esse cenário reverbera e é revelador das tensas fontes da vida moderna em nossos dias. O que nos fez chegar até aqui foi um empenho individual e coletivo: lutas, palmo a palmo, mas não sem as necessárias cessões estratégicas, com a realização de recuos históricos, mas também incluindo avanços corajosos. Esse conjunto de avanços e retrocessos não marca nenhuma espécie de convicção reta dos agentes históricos acerca do valor da democracia em si mesma. Hoje, como sempre, pulsa no âmago da política a tensão entre oponentes ideológicos radicais forcejando por ideias e ideais contraditórios que, com maior ou menor intensidade, procuram vazá-los do mundo abstrato da mente ao concreto da esfera temporal. Não raro, é utilizada a estratégia de travestir os interesses privados em interesses coletivos que, em verdade, não passam de meras estratégias políticas desenhadas para a concretização de um único fim privado de ordem econômica, categoria cuja realização permite o desdobramento em múltiplas benesses ao servir como gazua para os mais altos e maciços portões das facilidades da vida. Portanto, é na reafirmação da atual política aplicada em matéria econômica que encontramos o núcleo duro de um embate cuja raiz é de ordem filosófica; tal reafirmação reconstrói e reforça o discurso entronizador das liberdades (de comércio e contratação), da administração (otimização dos recursos humanos), da economia (maximização das unidades de produção) e do direito (consolidação e aperfeiçoamento das garantias à propriedade, aos contratos e, por derivação, incremento da segurança jurídica). Com isso é reforçada uma carapaça argumentativa para o discurso do triunfo das elites de sempre, para a garantia de manutenção do sistema em perfeito desequilíbrio em prol do capital sob a aparência jurídica, política e econômica, de que equilibrado está ou, em momentos de séria ameaça de emersão da percepção pública, de que o sistema está empenhado na busca do sempre anunciado equilíbrio.

A rigorosa e dura rigidez dos instrumentos ideológico-políticos foi capturada e ora está sob o controle de forças econômicas que operam autonomamente, sem que lhes fosse devidamente cedida a posição de controle e, é certo, ainda menos a 
do exercício de profunda dominação sem claras contrapartidas sociais, políticas ou econômicas, visto que nos momentos difíceis não são os beneficiários de sempre os que são chamados a saldar o prejuízo. Esse grupo oligárquico no poder não cessa de interagir articuladamente ao arrepio de qualquer arranjo político ideado, e nesse ponto referendamos Wright Mills ao afirmar que "Ya no hay, de una parte, una economía, y de otra parte, un orden político" (1989, p. 15). Já não haveria, sequer, uma ordem política que organizasse a competição social que a sociedade liberal tenta oferecer em condições de relativa equidade, pelo simples fato de que ela foi corroída desde dentro em suas mais relevantes instituições, corrosão que tem atores, e atores que fazem triunfar seus interesses específicos.

O establishment mantém a(1)tivo o discurso do emprego de esforços pela concretização da igualdade de oportunidades. Entretanto, ainda que esse objetivo fosse alcançado em níveis apreciáveis, isso de pouco valeria em face das distorções que sempre garantem o resultado final indefectivelmente favorável aos oligarcas. Todos com acesso a crédito prévio para adentar no cassino e sentar-se à mesa de jogos; todos dispondo de bônus para manter em nível alto a motivação para a constituição mais profunda de um espírito popular estoico bastante conveniente; todos sentados à mesa com liberdade para realizar suas apostas nos números e cores de sua preferência, sem embargo, ainda antes de a esfera deslizar na circunferência côncava medianamente abaulada, sem que saibam os incautos jogadores, já está desenhado o cenário de sua desventura que também atinge a convicção do homem médio ao sentir a impostura como se fosse real, como se o ambiente exalasse genuinamente um frescor apenas típico de um sistema de liberdades.

O sistema de liberdades pressupóe que a política seja realmente o reino em que o dissenso impera e os esforços pela intermediação são contínuos, voltados ao distensionamento e à dissuasão da radicalização em prol da manutenção das negociações. Nesses cenários em que a verdade é exaltada e tomada como base legitimatória das forças políticas em posição de poder, restam politicamente violados seus atores sociais para o que, de fato, representa a ação e um projeto político voltado à garantia das liberdades. A postura de asseverar a verdade como a base da política estatal apenas caracteriza a ineludível marca de um regime tirânico, visto que a democracia está assentada, inexoravelmente, sobre o dissenso. O que está de fato em questão para que seja possível avaliar o grau de qualidade de uma democracia são precisamente os instrumentos de que dispõe a população para veicular seu dissentimento e suas aspirações, são os mecanismos disponíveis para que o conflito encontre causação por vias dialógicas e não de puro enfrentamento ou, inversamente, de obstaculização dessas manifestações, que apenas caracteriza um regime de força, seja ela explícita (violência física) ou não (violência formal). 
Nesse horizonte social e institucional de consolidação da verdade, o litígio não tem lugar e o conflito (marca das liberdades) não se estabelece, pois o dissenso não pode ocupar a praça pública e reclamar a atenção do auditório quando a verdade ali está acampada de forma espaçosa. Assim imposta pelo regime, a verdade tem a pretensão de substituir a percepção sensorial e cognitiva do mundo empírico, sempre atualizada pelo regime a tentar convencer os atores, para que permaneçam sob a ilusão da aplicação das regras do jogo e do adequado funcionamento do sistema. Quando a verdade toma assento, portanto, quem conduz a política é uma oligarquia no poder; quando esta via é desobstruída, as condições de possibilidade para uma democracia são instauradas.

O controle sub-reptício da ordem vislumbrado no conjunto das democracias ocidentais por parte dos grandes oligarcas insiste em oscilar o sistema a favor de seus interesses: eles assistem impassíveis a toda encenação e sofisticação dos discursos políticos e das retóricas decadentes em prol do suposto abrigo aos direitos, devidamente instalados em seus luxuosos camarotes, nos quais indefinidamente pretendem continuar a desfrutar das benesses da fraude sociopolítica e econômica concretizada por seus exclusivos representantes empoderados extrassistemicamente: os executivos-políticos. Desse modo, restam plenamente desconstituídas quaisquer políticas de equalização das condições e das oportunidades inicialmente distribuídas, e cujo impacto final será apenas o de potencializar os parâmetros da derrota dos jogadores, visto que os mantém estáticos em sua posição de apostadores alimentados pela ilusão continuada de vitória em uma próxima rodada.

Em um quadro de domínio disseminado do poder econômico, parcela de sua força migrou para exercer o controle da esfera política e, assim, garantir a um grupo de oligarcas a direção das políticas públicas, redimensionando-as mediante a ação dos representantes políticos expressa e formalmente eleitos pela população. Nesse contexto encontram espaço as forças que aspiram à constituição das formas autoritárias, cujo movimento ordinário é, sub-repticiamente, proceder ao realinhamento da democracia sob novos parâmetros e gramática, ainda que com o cuidado de manter o vocábulo intocado. Mantêm o vocábulo e desconstroem a prática da gramática, montando a equação da democracia sem democracia ou a concepção arquitetônica bem-acabada de uma nebulosa antessala do despotismo democrático à espera de um autoritarismo preparatório da pura ditadura. Não obstante, embora seja mantido o vocábulo democracia, passamos a experimentar uma nova ordem fática, em que o conteúdo da democracia foi sendo progressivamente alterado. 
Oligarquias, dominação e formas retóricas

A ponte de ligação das oligarquias com a democracia se dá no nível discursivo, isto é, a forma de penetração buscada é a retórica através dos meios de comunicação de massa e do poder persuasivo do consumo de massas, aprofundando, desse modo, a tendência oligárquica cuja absolutização é indicada por Zagrebelsky (2011, p. 22) como de inequívoca resolução em regimes de tirania, sejam eles operantes na esfera política, ideológica ou econômica ou, talvez, combinando diversos desses elementos. O instrumento concreto de ligação, portanto, é a mídia, e controlar a emissão de conteúdos passa a ser vital para o cumprimento das aspirações de manutenção do domínio sob uma determinada configuração cultural que capitaneia, mascaradamente, a ideologia em vigor que, mesmo hoje, se apresenta como se nada estivesse sendo defendido, ou seja, sob a pretensão da política como mero reino da otimização da técnica e da gestão de recursos.

Ao reconhecer a centralidade do controle do discurso público para coordenar e conduzir os processos políticos de legitimação do sistema, resta consagrada a importância do controle das formas de expansão ideológica. Elas são indispensáveis para a legitimação do sistema, e a estratégia oligárquica de domínio da pauta do debate se faz acompanhar de cinismo diante das práticas políticas (mas não no discurso) da democracia. Há nesse passo a aplicação da dose de hipocrisia necessária para manter o equilíbrio entre os interesses dessa elite no poder e o disfarçado exercício de sua dominação para, paralelamente, seguir mantendo o equilíbrio sistêmico indispensável. Nesse cenário, é um imperativo político que a oligarquia continue a empregar esforços na sofisticação de sua retórica legitimadora, dando curso não só à sua publicidade, mas também, em paralelo, às estruturas repressivas, quer pela via do controle dos direitos trabalhistas, sociais, quer pela coerção dos aparelhos do Estado. Sendo exitosa nesse movimento, a oligarquia compromete o coração da democracia, visto que a neutraliza em aspecto capital, qual seja, o de que o sistema esteja voltado a produzir efeitos para todos, que seja bem mais do que um mero sistema de crenças e princípios compartilhados, mas que, na prática, sejam traduzíveis os seus princípios em políticas, e ambos em uma coletivização do bem-estar que cada qual a seu modo e entendimento efetiva e alcança.

As oligarquias lançam mão de múltiplos artifícios e manobras diversionistas para cumprir o mister de distanciar os atores sociais de uma boa percepção das estruturas que realmente exercem o mando político. Assim, exercem função importante o conjunto das iniciativas em matéria de publicidade e as promessas nela inseridas, criando cenários ilusórios retrospectivos e prospectivos, apontando para a possível materialização uma vez cumprida a condição de uma dedicada aplicação dos indivíduos aos 
mandatos do sistema, que reclamam homens estoicos no presente a fim de alcançar as condições para o ser hedonista, quando, em realidade, esse quadro de esperanças falsamente desenhado pode constituir o que Boaventura de Sousa Santos (1999, p. 105) qualifica como fascismo populista, preocupado em democratizar estilos de vida e de consumo fora do alcance da maioria da população, embora, muito habilmente, o establishment faça transitar essa inviabilidade concreta pela colonização do mundo da esperança, articulando o discurso pela sutil via da publicidade constante. Mas esse horizonte (falsamente) brilhante e (falsamente) alcançável não o seria assim facilmente, senão que, pomposamente, o sistema exige de seus indivíduos o cumprimento de pura eficiência e a maximização radical de recursos, reforçando os mecanismos de sofisticação da economia, como se esta fosse operável à margem e ao isolamento completo da condição humana, desconsiderando que, essencialmente, a compõe e constitui a sua inexorável razão de ser e finalidade última.

As possibilidades de alternância dos fundamentos da organização do Estado (lato sensu) que estejam voltadas a privilegiar o desenvolvimento humano quando em dissonância com a potencialização dos interesses oligárquicos são irremediavelmente ocultadas. As vias de alternância política e econômica são escamoteadas ao debate público pela eficiente organização da pauta ideológica desenvolvida pelos meios de comunicação, cuja conexão íntima com as oligarquias os leva a privilegiar o aprofundamento dos princípios orientadores do regime e sua organização econômica e política. Essa atividade de reforço ideológico subtrai a essência analítica do sistema de seu núcleo reflexivo e efetivo controle, pois retira do debate público até mesmo a mera hipótese de elucubrar alternativas teóricas que divirjam do establishment.

Esse necessário esforço continuado pela higidez das políticas e das instituições democráticas, contudo, não pode sobreviver sem a existência de vias disponíveis para a competição entre os discursos e os meios de publicizá-los. Rigorosamente, esse propósito depende não apenas de vozes, mas também de aparatos para que as ideias sejam comunicadas e apreciadas pelo conjunto dos cidadãos. A crítica, portanto, não sobreviverá isolada na mente de um cidadão ou em um grupo deles; não pode, por conseguinte, sobreviver de forma residual e apartada do âmbito social, e é daí que deriva a importância visceral da mídia e da forma como a sociedade reflete sobre o seu papel e sobre como o Estado, a partir dessa análise, se comporta e legisla sobre ela.

O que está em causa é o solapamento das vias alternativas à ordem econômica, e o que precisa ser considerado é a razão de não estar em pauta um debate essencial sobre os reais custódios do poder. Propor a discussão pública da operatividade dessas forças oligárquicas dispõe de potencial para fazer transparecer a esfera do real. Para as oligarquias isso coloca em xeque as premissas do sistema. A concretização de um 
sistema que combina a interdição do diálogo político com a centralização das decisões em corpos ocultos é a chave acionadora da decadência da democracia. Há uma conexão entre essa interpretação e a urgência ínsita à avaliação de Mészáros acerca de que "É preciso sair desse círculo vicioso autodestrutivo com seus processos de tomada de decisão alienados sobrepostos sobre as pessoas” (2015, p. 21). Essa sobreposição é uma descrição adequada de uma via antidemocrática sólida.

A formatação do discurso ideológico ocorre em um panorama unitário, homogêneo, mas que pretende ser reconhecido como se fosse plural e heterogêneo, como sensível ao conjunto de diferenças culturais que definem a convicção pluralista (ver Nussbaum, 2005, p. 33). O movimento ideológico pela homogeneização é tão potente que o seu alto grau de corrosividade tem potencial destrutivo da própria democracia (Todorov, 2012, p. 20). O que se observa nesse movimento é o anseio de realizar a plenitude de uma formatação ideológica de viés unitarizante, mascaradamente dissociada da democracia, que tem um corte pluralizante. O conjunto dos discursos homogeneizantes oscila em torno de variações ao sistema, sendo eles analíticos, mas operativos sobre a unicidade de fundo que os inspira, rechaçando novas alternativas como fugidias à consolidação do avanço e ao suposto progresso já alcançado. O que está em causa é o bloqueio à discussão de ideias, a má e comprometida divulgação de informações e a introdução de análises inconsistentes sobre o sistema em vigor. Isso prejudica um dos fundamentos da democracia, a saber, a conflitividade.

Indubitavelmente esporádicas, modestas e, ainda, escassamente estruturadas quanto à sua sistematização, as ações sociais requerem maior organicidade interna a fim de projetar impacto no campo político. Essa debilidade é reveladora da insuficiência da presente organização da sociedade para reagir às estruturas de poder, em especial a uma de suas limitações mais importantes, a saber, o individualismo radical. É este que estimula uma sociedade atomizada, geradora da inércia em termos coletivos. Esta é uma plataforma política hábil para a promoção do poder oculto que solapa as bases da democracia, a qual encontra um de seus eixos justamente no compartilhamento de poderes (Brown, 2010, p. 73), com tudo o que isto supõe em termos de instrumentos de participação, manifestação de vontade e, em suma, influência sobre as instituições.

Sob tão amplo quanto intenso conjunto de promessas materiais das quais o sistema dominante lança mão, eis que, no horizonte, levitam os olhares das hipnóticas sereias de Ulisses. São elas que galvanizam a atenção dos marujos mal equipados de uma nau comprometida, tripulação forjada para solitariamente experimentar a dureza do rochedo, toda ela balançada pelo som sedutor do equilíbrio da voz e da ondulação do mar. Efeito hipnótico que também vem surtindo a melodia ideológica, hoje imposta com o vigor de uma corrida sem destino nem objetivo, quer evidente ou implícito, 
sob um ritmo alheio às possibilidades de composição de significado ou atribuição de sentido à vida ou às circunstâncias que cercam o indivíduo e a comunidade. As melodias que se repetem em todas as frequências sob formas pretensamente analíticas adotam aparências diversas, mas são meras reiterações melódicas (eficiência, maximização, produtividade etc.), aplicadas à saúde e à educação, ao pensamento e às relações humanas ordinárias, em um esforço superlativo para traduzir em números e estatísticas disponíveis a apropriação pela economia.

O projeto político-econômico aplicado pelas democracias ocidentais penetrou corações e mentes de seus cidadãos, ganhando mais do que meros adeptos. O projeto é apresentado como se fosse o verdadeiro equivalente teórico das democracias no plano da prática política, sublinhando com ligeireza e debilidade argumentativa que a escolha política periódica pode ser designativa da centralidade de suas virtudes. A sustentar o discurso sobre a vida e as formas econômicas, é notável a elaboração em paralelo de um discurso bem montado acerca da necessidade de segurança sistêmica. Sem embargo, a lógica da segurança e da imposição do sofrimento supostamente em prol de um futuro melhor permanece firme, como se não houvesse nenhuma outra alternativa possível. Em verdade, o que está em questão não é a falta de opções, mas o fato de que vivemos em um tempo de exceção utilizado pela oligarquia para impor uma visão única e excludente, ou seja, está em causa a aplicação de uma entre as múltiplas opções políticas, de uma mera opção política, uma astuta articulação ideológica por parte do restrito grupo de detentores do poder econômico, cujo núcleo duro visa a neutralizar o poder político a baixo custo. Empenha-se em cumprir seu desiderato retoricamente, sob o argumento de que está a empregar esforços para uma segurança sistêmica superior e para a estabilização das condições de produção econômica e da reprodução das condições jurídicas, políticas e materiais. Mediante interdição ao debate público, foi realizado com êxito um processo de naturalização não apenas do discurso econômico, mas também das graves consequências de não segui-lo à risca, isto é, mantendo ocultos tanto seus efeitos deletérios (assim como os efeitos nem sempre controláveis), capazes de serem produzidos sobre as instituições democráticas, como as reais alternativas em matéria de política econômica.

\section{Considerações finais}

A tentativa dos poderes invisíveis de realizar a apropriação completa da esfera da política os coloca em posição pública de atores que desequilibram um processo social já por natureza de assimetria pronunciada, cuja condução por especialistas está a ponto de realizar o desequilíbrio ideal. Aqui, novamente, e em sentido inverso, o que está em curso é a realização da promessa redentora implícita, ou seja, de promover a 
salvação pelo signo da falsificação de aconchego no reino da absoluta eficiência. $\mathrm{O}$ que está em causa, portanto, é a massificação de uma ideologia voltada à maximização de uma concepção ilimitada da eficiência a qualquer custo (humano inclusive), que desloca o político de sua função precípua bem como sua categorização temporal, entronizando as categorias econômicas conjugadamente ao reino da burocratização da vida, que a tudo operacionaliza sob as cegas ordens constituídas na esfera das decisões não democraticamente estabelecidas. As mãos e as faces antes invisíveis que operam o campo político e tomam as decisões no mercado vinculam os operadores políticos e progressivamente, conforme a certeza da rendição do pensamento, essas forças vão se sentindo mais desinibidas para apresentar seu discurso com ainda mais intensidade, sejam eles atores econômicos privados ou públicos. É preciso realizar o movimento encorajador de recompor o homem com a criatividade institucional que ficou em suspenso desde que o mercado assumiu a posição e o poder para "moer o tecido humano" (Polanyi, 2013, p. 98), algo que o poder econômico realiza, cegamente conduzido pela realização de seus interesses. A tarefa da retomada da política democrática implica identificar perfeitamente e tornar visíveis as forças que operam nas sombras da democracia voltadas ao seu solapamento.

Essas ações ideológicas sobre o mercado impuseram, e por fim naturalizaram, a noção de que o tempo não está à disposição do político, e mais, de que não pode mesmo ser colocado em tal posição. Ao realizar esse movimento, as ações ideológicas deslocaram e bloquearam a percepção de um futuro aberto e possível no plano empírico, embora topicamente a retórica apresente tal expectativa como viável. O político precisa necessariamente manter disponível o futuro, pois assim estará representando a esfera remanescente de cultivo da esperança e de mobilização de forças que adaptem o real ao onírico. Quando a ideologia se torna estática é pela intervenção de duas forças, a saber: por um lado, um suposto triunfo ideológico irretorquível; por outro, a poderosa inflexão da inércia imaginativa, capaz de tornar o status quo ideológico revestido da aura de uma (falsa) petrificação com ares de dureza inabalável. Por trás disso há um movimento de regresso a uma concepção passiva do homem e de sua forma de inserção no mundo, submetido ao azar da ação dos deuses que o organizam. O Kairos não falta, mas sim o ímpeto a atores que precisam re-conhecer os movimentos subterrâneos que coordenam o real.

O ímpeto está sempre disponível para a apropriação pelo espírito. Sem embargo, tem faltado a ousadia para incorporar esse requisito da ação com tanta coragem quanto desapego, e esse passo sugere o descortinamento do horizonte institucional por parte dos atores sociais, acompanhado de efetivo empenho para a sua apropriação e transformação. A resignação alimentada pelo status quo desestimula tal movimento e por adormecimento ameaça com uma irreversível perda da riqueza 
da força imaginativa humana (Polanyi, 2013, p. 98). Essa força já reconheceu nas linhas de Shakespeare o tamanho de sua maldição, marcada por vir ao mundo para endireitá-lo (Shakespeare, s/d, p. 52), algo que bem dá a dimensão de nossa insuficiência humana para tanto. Contudo, algumas pistas e vetorializações são possíveis elementos alentadores.

Uma das vias de pavimentação para uma sólida alternativa ao estágio organizacional da sociedade atual, tanto no aspecto político como econômico, diz respeito ao aprofundamento da tarefa de sofisticação do processo educacional apropriado pelas classes populares, pois a realização prática da autonomia através de sua inflexão no campo jurídico-político está na base da constituição de uma democracia substantiva (Mészáros, 2015, p. 22). Já não se trata, portanto, de focar intensamente os recursos materiais, mas, sim, a concepção metodológica, ideológica e filosófica que inspira o processo, angulação que precisa priorizar a preocupação com o desenvolvimento crítico-analítico dos sujeitos da educação. Esta é capaz de interessar o homem a tornar-se autor de si mesmo e edificar suas circunstâncias, tanto pessoais como sociais - estratégia que pode servir de momento consolidador a um primeiro passo para subverter a realidade de forma necessariamente menos sofisticada.

Entretanto, a intervenção nos dias que correm sugere a melhor descrição possível do tempo presente, e este é, realmente, de pessoas entrincheiradas, apequenadas por desprezíveis estímulos externos de ordem sistêmica conjugada com sua própria inação, vivendo um mundo de perspectivas decrescentes, que apontam para o distanciamento da apropriação do seu imaginário social, semeando o cenário de um futuro de incertezas destituído de esperanças. A perspectiva descritiva, em alguma medida, não supõe a inviabilidade de sua superação. A inversão de rumos é factível, podendo os homens adiantar o Kairos histórico, que não é dado naturalmente, mas elaborado, quiçá, no curso de gerações, talvez como o trabalho do ourives anônimo, à diferença de não conhecer o momento sequer da aproximação de sua finalização.

Admitindo o fato de que se encontra fechada a passagem ao visceralmente novo pela via da imaginação social, ela precisa ter forçado o seu parto, ao tempo que pavimentado o seu porvir pela via da sofisticação de seus atores. Sua incidência no real se dá pela reconstituição da ação política, atividade que veio sendo paulatinamente desconstruída através de sua transformação em mera gestão por parte do conjunto de poderes articulados. Urge o estabelecimento de rotas de fuga ao já posto pelas vias do Kratein democrático que é, por excelência e definição, denotador de ruptura com os poderes exercidos desde as sombras. Este é um momento de tensão que descortina o horizonte para a realização do Kratein democrático em sua essencialidade, a radicalidade possível da libertas do homem, e não um mero processo de subversão para reafirmar o mesmo com novos atores. 
Via contraditória à visão de mundo oligárquica, pois segundo o desenho da democracia emerge uma configuração de "um espaço comum, de tal modo que possa abrir-se nele toda a riqueza possível das formas que o infinito é capaz de adotar, das figuras de nossas afirmações e as declarações de nossos desejos” (Nancy, 2010, p. 49). A projeção concreta do imaginário desenha um horizonte que reclama atores para a constituição de um espaço real que apenas pode ser compartilhado por aqueles que se colocam em posição de igualdade. Essa é uma perspectiva algo fugidia ao espírito triunfante do oligarca, que desprivilegia a atenção para a instauração desse espaço comum, senão que a sua perspectiva é a da constituição de um espaço comum particular para seus semelhantes, entre aqueles que compartilham o estabelecimento do mundo de puro domínio das organizações econômicas e políticas. Essa intervenção conservadora interdita o descortinamento dos futuros possíveis a partir do desenvolvimento do imaginário de atores sociais, cujo interesse desinstrumentalizado é o de dar curso à venturosa caminhada, atribuindo sentido e (res)significações inauditas às suas vidas privadas e também à esfera pública em que lhes toca viver. Encontrar o sutilíssimo filete que vaza a rocha por onde possa transitar o imaginário mais potente e que possa colonizar o mundo real, ainda mesmo sob o clima de múltiplas interdições que pairam sobre o presente, este, justamente, é o verdadeiro desafio que se projeta sobre o futuro.

É a percepção do real e de suas estruturas em sua inexorável contingência o pressuposto para o descortinamento do amplo conjunto de possibilidades de que se compõe o porvir, mas isso certamente não é o suficiente. É necessário proceder à des-coberta das instâncias e dos atores que condicionam o presente, é imperioso fazê-los emergir das sombras em que operam como precondição para que a intervenção do imaginário sobre o futuro possa desfrutar de real expectativa de concretização. A exposição dessa circunstância é tão somente o pressuposto para que os atores libertários, populares e democráticos possam realizar sucessivas (re)apropriações e redesenhos estruturais do futuro, que nunca podem ser infrapostos aos interesses materiais radicalmente afirmados das oligarquias, pois essa é uma das chaves da compreensão razoável da justiça humanista libertária. Ele precisa ser preenchido materialmente uma e outra vez, de forma constante, embora sempre parcialmente, sempre peça por peça, tal como um quebra-cabeças infinito cuja marca é a impossibilidade de sua finalização, e para tal movimento não há uma definição precisa de estratégia e de escolhas, senão procedimental, sob pena de que o futuro fique fechado ao imaginário, sempre recondicionado e redirecionado pelos sucessivos atores históricos.

Não há titulações ou empoderamentos formais suficientes para habilitar a transformação pelo imaginário democrático quando seus atores não dispõem de capacitações e competências; não há pluralismo razoável consagrador dos diferentes quando 
essa precondição não é assumida na prática das instituições sociais. Quando falamos de uma sociedade justa como legado para as gerações futuras, não estamos a falar de uma concepção preconcebida e bem-acabada, pois seu mero ato de fechamento equivale a aprisionar no passado que hoje ainda é presente os que virão. Esta é uma percepção política que carrega consigo doses modestas e equilibradas de otimismo e ceticismo em suas perspectivas descritivas e normativas. De forma congruente, portanto, o presente texto aponta para a importância do mero descortinare, para isso, do papel a ser desempenhado pela igualdade de competências como forte e incisiva arma libertária, pois através dela podemos realizar uma aproximação razoável ao quão realmente capacitadas estão as pessoas a ser e fazer, tanto no que concerne a si mesmas como na intervenção no coletivo em que estão inseridas.

O mais expressivo e consistente legado político libertário apenas pode estar calçado em perspectiva similar à shakespeariana, para quem "Não se constrói em sangue; vida alguma/ tranquila pode haver com a morte de outrem" (Shakespeare, 1955, p. 84), mesmo por conta de que cetros arrebatados pela força e violência precisam recorrer aos mesmos processos para que possam manter o poder. Opção inversa, a re-construção da esfera pública requer mais esforço com base em outra perspectiva, a saber, a ampliação de capacidades e competências habilitadas para descortinar a riqueza de horizontes. Tal abertura interdita a antecipação das figuras a serem formadas, mas sempre mantendo aberta a esperança coletiva de uma figura visionária, algo que, certamente, um tabuleiro composto por figuras finitas não permitiria. Há que mobilizar forças já não para derrotar o erro, o que designaria uma cosmovisão fechada, mas, antes, para descortinar o engodo, discernir caminhos e, sem declarar status belli configurador do inimigo à morte, aclarar horizontes compreensivos que expressem o que Mészáros define como redefinição qualitativa de nossa ordem social (Mészáros, 2015, p. 21). Empregar forças para que seus agentes concretizem tempos de eternização no presente, mas cuja abertura não prescinda de novas redescrições que sejam suplantadas por novas perspectivas de eternidade. Estas, por sua vez, também resultarão transpassadas pelo inesgotável porvir, orientado pela sede coletiva de alimentar o futuro com sua própria seiva, e não com a alheia, segundo sua própria imaginação, e não pela incidência determinante e excludente dos demais.

A ação coletiva voluntariosa e realizadora é potencialmente desbravadora de promissoras trilhas, ação capaz de desobstruir o conjunto de dificuldades artificialmente impostas por um obscuro conjunto de atores que fortalecem a escuridão da mata política sob a qual operam de forma sub-reptícia para cumprir seus fins. Paradoxalmente, o caráter enigmático desses espaços fechados pode ser mobilizador da imaginação e de esforços que apontem para possibilidades ainda não exploradas, sendo que a consecução deste novo cenário fica na dependência de uma conjugada 
emergência poderosa da coragem pessoal e da ousadia institucional de seus atores políticos populares. Seu caráter aberto e destemido permite antever um porvir radiante que não se confunde com alguma fantasia absolutamente ociosa do espírito, mas está conectado à orientação dos atores segundo a dinâmica do tempo em que eles se apresentam como partícipes de um jogo inesgotável, cujas sucessivas consecuções bem-acabadas requerem, contudo, perfis de intérpretes interessados em provocar radiações coletivas sensíveis. Tais finalizações provisórias na história são concretizáveis pela via da intensificação de articulações sociais populares sempre dependentes da ação de esperança capaz de mobilizar politicamente, mas também disposta a configurar o futuro de modo aberto, inversamente à dinâmica cristalizadora medieval, generosa oferta que as oligarquias de modo algum possuem do alto de suas pirâmides de riqueza e poder. Inversa é a via para zarpar rumo ao futuro.

\section{Referências Bibliográficas}

Brown, Wendy. (2010), "Ahora todos somos democratas". In: Agamben, Giorgio et al. Democracia en suspenso. Madri, Casus Belli, pp. 59-78.

Galli, Carlo. (2013), El malestar de la democracia. México, Fondo de Cultura Económica. Gauchet, Marcel. (2012), A democracia entre duas crises. Lisboa, Editorial Presença. Heller, Ágnes. (1980), El hombre del renacimiento. Barcelona, Ediciones Península. JASPERS, Karl. (1933), Ambiente espiritual de nuestro tiempo. Barcelona, Editorial Labor S. A. McAfee, Noëlle. (2008), Democracy and the political unconscious. Nova York, Columbia University Press.

Mauro, Ezio \& Zagrebelsky, Gustavo. (2011), La felicità della democrazia: un dialogo. Roma-Bari, Laterza.

MÉsZÁros, István. (2015), A montanha que devemos conquistar. São Paulo, Boitempo Editorial. Nancy, Jean-Luc. (2010), Democracia finita e infinita. Madri, Ediciones Casus-Belli.

Nussbaum, Martha. (2005), Capacidades como titulaciones fundamentales: Sen y la justicia social. Bogotá, Universidad Externado de Colombia.

Polanyi, Karl. (2013), Nuestra obsoleta mentalidad de mercado. Madri, Escolar y Mayo Editores. RANCière, Jacques. (2010), Las democracias contra la democracia. Madrid, Ediciones Casus-Belli. . (2012), El odio a la democracia. Buenos Aires, Amorrortu.

Rosanvallon, Pierre. (2014), Le parlement des invisibles. Paris, Seuil.

SANTOS, Boaventura de Sousa. (1999), “Reinventar a democracia: entre o pré-contratualismo e o pós-contratualismo”. In: Oliveira, Francisco de \& Paoli, Maria Célia (orgs.). Os sentidos da democracia: politicas do dissenso e hegemonia global. Petrópólis/Brasília, Vozes/Núcleo de Estudos dos Direitos da Cidadania (Nedic)/Fapesp, pp. 83-129.

Shakespeare, William. (s/d). Hamleto. Principe da Dinamarca. 2. ed. São Paulo, Melhoramentos. 
(1955), Vida e morte do Rei João. São Paulo, Edições Melhoramentos.

Todorov, Tzvetan. (2012), Les ennemis intimes de la démocratie. Paris, Éditions Robert Laffont. Wright Mills, Charles. (1989), La élite del poder. México, Fondo de Cultura Económica.

Zagrebelsky, Gustavo \& Mauro, Ezio. (2011), La felicità della democrazia: un dialogo. Roma-Bari, Laterza.

\section{Resumo}

Democracia ou oligarquia? O controle invisível da política

O que é democracia, como e de que forma ela vem sendo gerida e apresentada à população? Há discrepância entre o núcleo de suas instituições e a sua prática? Considerando o cenário político comum das democracias ocidentais, este texto detém-se nas formas de controle e nos instrumentos institucionalizados para bloquear a participação política. O autor parte da hipótese de que está em fase final nas democracias contemporâneas um processo de substituição das instituições democráticas em prol da instalação de uma oligarquia no poder, não obstante a manutenção formal das instituições democráticas. Analisam-se as condições em que esse poder oligárquico coordena seus interesses econômicos e políticos de forma invisível.

Palavras-chave: Democracia; Oligarquia; Invisibilidade; Política.

\section{Abstract}

Democracy or oligarchy? The invisible control of politics

What is democracy, how and how is it managed and presented to the population? There are discrepancies between the core of its institutions and its practice? Considering the common political scenario of Western democracies, this text focuses on forms of control and institutionalized instruments to block political participation. The author starts from the hypothesis that a process of substitution of democratic institutions for the installation of an oligarchy in power, despite the formal maintenance of democratic institutions, is in the final stage in contemporary democracies. We analyze the conditions under which this oligarchic power coordinates its economic and political interests in an invisible way.

Keywords: Democracy; Oligarchy; Invisibility; Politics.

Texto enviado em 7/10/2015 e aprovado em 7/7/2016. Dor: 10.11606/0103-2070.ts2017.10 5569.

ROBERTO BUENO é professor adjunto III da Universidade de Brasília (UnB); doutor em filosofia do direito pela Universidade Federal do Paraná (UFPR) e pós-doutor em filosofia do direito e do Estado pelo Centro Universitário Eurípedes de Marília (Univem); .E-mail: rbueno_@hotmail.com. 